
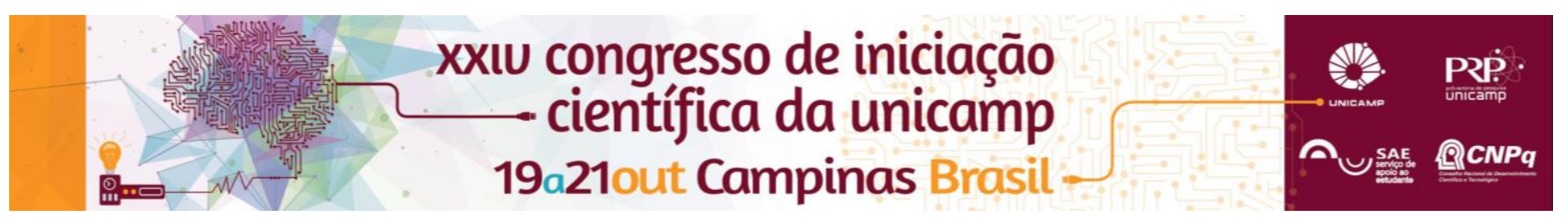

\title{
Tridimensionalidade e apropriação na obra de Adriana Varejão e Rosângela Rennó: deslocamentos e ressignificações no espaço expositivo
}

\section{Caroline Scarpelin}

\section{Resumo}

Esta pesquisa analisa as instalações de Adriana Varejão e Rosângela Rennó no que se refere as suas características de apropriação imagética e documental e de construção espacial, assinalando possíveis relações com a sensorialidade e a memória despertadas no trabalho dessas artistas.

\section{Palavras-chave}

Palavras Chave: Adriana Varejão, Rosângela Rennó, instalação.

\section{Introdução}

Fruto de um cenário artístico nacional rico em hibridismos e possibilidades construtivas, que se volta tanto para questões da individualidade autoral quanto para problemáticas sociais, os trabalhos de Adriana Varejão e Rosângela Rennó abordam ao mesmo tempo memória particular e partilhada, fator possibilitado pela apropriação de registros imagéticos da história da arte, história geral e histórias atuais como um todo, e de arquivos públicos e privados descartados, respectivamente. Partindo dessas características, as instalações dessas artistas possuem um sentido de deslocamento sensorial, tanto no que tange a sua construção espacial, que insere o observador num tempo-espaço aparatado, próprio da instalação, quanto no sentido de transportá-lo para os inúmeros tempos das imagens apropriadas.

\section{Resultados e Discussão}

A construção espacial nas obras de Adriana Varejão e Rosângela Rennó ocorre de diferentes maneiras e propõem questões distintas: no caso de Varejão, ela se dá através da mimese produzida pela pintura, que ganha novos aspectos, como o de pele, carne e de espelho, verificados nas instalações Extirpação do mal por incisura de 1994, Ruínas de charques de 2000-2004 e Reflexo de sonhos no sonho de outro espelho (Estudo sobre Tiradentes de Pedro Américo) de 1998, característica que aponta para certa teatralidade e uma preocupação narrativa produzida pelo meio pictórico; no caso Rennó, a construção tridimensional acontece no processo de organização do material fotográfico no espaço expositivo, criando instalações que aludem a outros tempos e espaços, como em Imemorial 1994, Bibliotheca 2002 e Experiência de cinema 2004-2005, fator que ativa a imaginação e empatia do público possivelmente pela trivialidade dos lugares aludidos (um memorial/cemitério, uma biblioteca e um cinema).

Figura 1. Linda do Rosário, 2004.

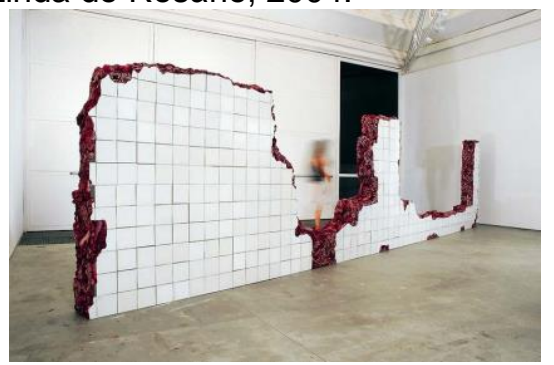

Figura 2. Imemorial, 1994

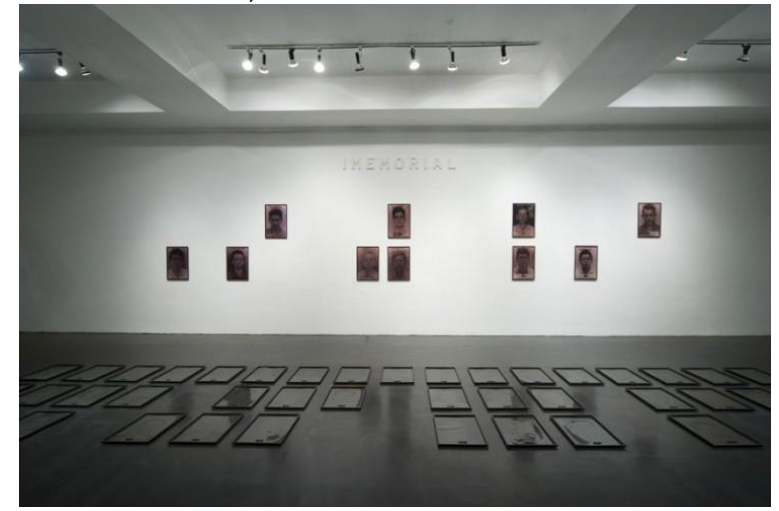

\section{Conclusões}

As possibilidades de deslocamento geradas pelas instalações de Adriana Varejão e Rosângela Rennó agem não só no âmbito particular das experiências sensíveis do observador, mas também como denúncia das problemáticas sociais atuais: tragédias provocadas pelo processo de urbanização, conflitos culturais e raciais, esquecimento político premeditado, descarte e apagamento da memória na atualidade são algumas das questões levantadas por esses trabalhos. Inseridas por meio da transposição para o contexto atual, as imagens do passado - seja ele distante ou próximo e sejam elas apropriadas de jornais ou livros de história da arte sofrem uma ressignificação no trabalho dessas artistas e constituem um dos fatores fundamentais de suas produções como um todo.

\section{Agradecimentos}

A minha orientadora Prof $^{a}$ Dr $^{a}$ Sylvia Furegatti, pela atenção e ensinamento e a minha família pelo suporte e incentivo plenos.

\footnotetext{
1 CHIARELLI. O Tridimensional na arte brasileira dos anos 80 e 90 genealogias, superações. In: FABRIS, A. Tridimensionalidade. São Paulo: Instituto Cultural Itaú, 1997. Pág. 170-181.

2 RENNÓ, R. Rosangela Rennó: o arquivo universal e outros arquivos. São Paulo: Cosac \& Naify, 2003. v1

${ }^{3}$ SCHWARCZ, L. M.; VAREJÃO, A. Pérola imperfeita: a história e as histórias na obra de Adriana Varejão. Rio de Janeiro: Cobogó; São Paulo: Companhia Das Letras, 2014.
} 